\begin{tabular}{|l|l|l|l|}
\hline Eiszeitalter u. Gegenwart & 35 & $\begin{array}{r}119-133 \\
6 \mathrm{fig} ., 2 \mathrm{tab} .\end{array}$ & Hannover 1985 \\
\hline
\end{tabular}

\title{
Some Preliminary Results on the Early Holocene Shore Displacement in the Oskarshamn Area, South Eastern Sweden
}

\author{
NiLs-Olof SvensSON *)
}

\begin{abstract}
Morphodynamics, shore displacement, lacustrine sedimentation, pollen diagram, C14 dating. South Eastern Sweden, Oskarshamn Area
\end{abstract}

A b s t r a c t : Pollen and sediment analyzes have been done in two lakes 16 and $26 \mathrm{~m}$ above sea level. The beginning of the Preboreal Chronozone is characterized by a regression, probably interrupted by a shortlasting transgression.

A rapid and quite significant transgression correlated with the Ancylus transgression begins ca. $9500 \mathrm{yr}$. B. P. at both localities. Between ca. 9000 and $8500 \mathrm{yr}$ B. P. the two sites were isolated, but at what altitude this regression ended is not yet known.

[Einige vorläufige Ergebnisse über die frühholozänen Strandverschiebungen im Oskarshamn Gebiet, südöstliches Schweden]

$\mathrm{Ku} \mathrm{r} \mathrm{z} \mathrm{f} \mathrm{a} \mathrm{s} \mathrm{s} \mathrm{u} \mathrm{n} \mathrm{g:} \mathrm{In} \mathrm{zwei} 16$ bzw. $26 \mathrm{~m}$ über Meeresspiegel gelegenen Seen sind Pollen- und Sedimentanalysen durchgeführt worden. Der Beginn der präborealen Chronozone ist hier durch eine Regression gekennzeichnet, die wahrscheinlich durch eine kurz dauernde Transgression unterbrochen gewesen ist.

Eine rasche und recht bedeutsame Transgression, die mit der Ancylus-Transgression korreliert wird, setzte in beiden Lokalitäten um ca. $9000 \mathrm{v}$. h. ein. Zwischen ca. 9500 und $8500 \mathrm{v}$. h. wurden beide Seen vom Meer abgeschnürt, aber es ist bislang unbekannt, in welcher Höhenlage diese Regression ausgeklungen ist.

\section{Introduction}

The early Holocene shore displacement in the vicinity of the investigation area has been studied by MuNTHE $(1902,1904)$ who during the geological mapping of the Kalmar Oskarshamn area and the island of Öland levelled the beach ridge corresponding to the Ancylus transgression. Thomasson (1927) divided the early Baltic development in the Kalmar area into phases based on pollen and diatom stratigraphy. In THOMAsson (1935) the phases are further subdivided. On Öland LuNDQvisT (1928) made pollenanalytical dating on organic layers below beach deposits corresponding to the Ancylus Lake, as well as on lake sediments with transgression sequences.

*) Address of the author: N.-O. Svensson, Fil. Kand, University of Lund, Dept. of Quaternary Geology, Tornavägen 13, S - 22363 Lund. 
KönIGSSON (1968) dates the Ancylus transgression on Öland with radiocarbon datings on pollen analysed profiles. This paper deals with the preliminary results from two out of several localities that will be used to determine the Late Weichselian and early Holocene shore displacement in the Oskarshamn area. Further work will be done on these two lakes with closer and deeper pollen analyses as well as diatom and grain size analyses. For comparison a study with the same aim is done on the island of Gotland (Svensson, in prep.).

The investigated lakes are situated west and southwest of Oskarshamn (Fig. 1) in a hummocky terrain with a granitic bedrock, mostly covered by thin till.

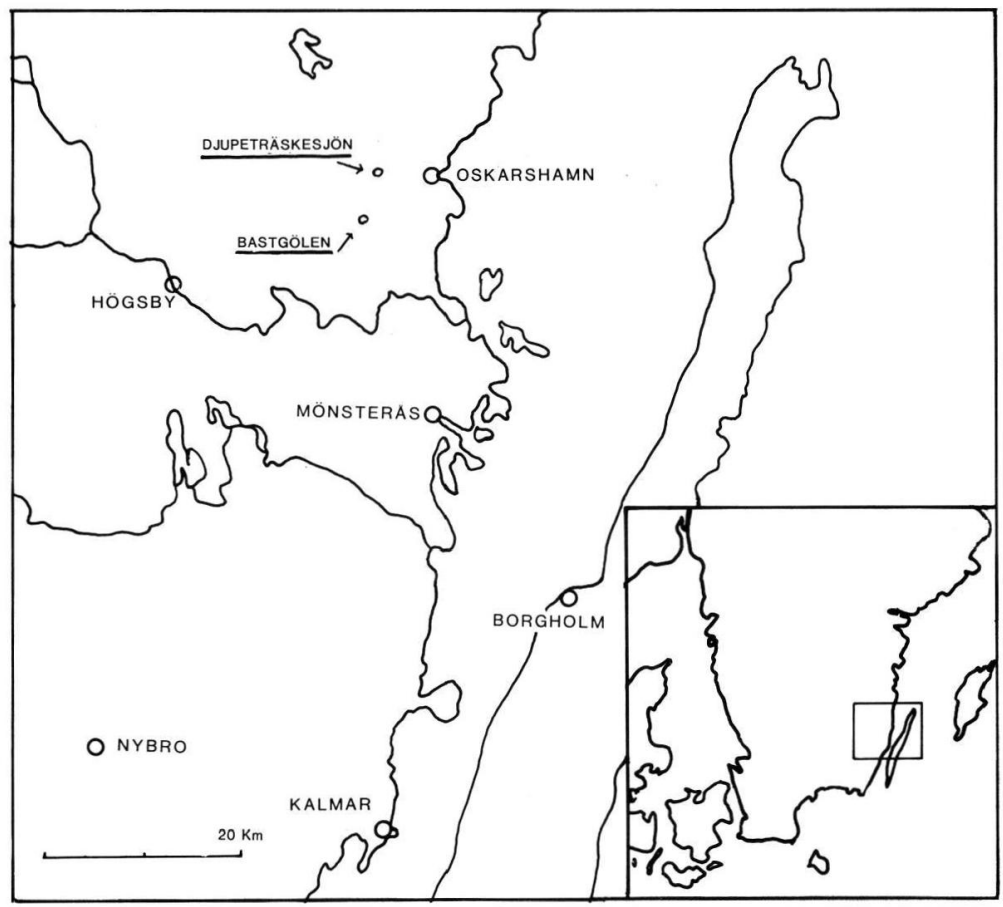

Fig. 1: Geographical position of the investigation area.

\section{Field and laboratory methods}

The coring was done by the Russian type of corer. The sediment is described according to TROELS-SMITH (1955). Pollen samples of $1 \mathrm{cc}$. were taken with a cut syringe, tablets with Lycopodium spores were added to determine pollen concentration according to STOCKMARR (1971). Pollen preparation was made in the usual way with $\mathrm{NaOH}$, hydrofluoric acid and acetolysis and mounting in glycerol. During preparation some extra steps vere introduced. After boiling in $10 \% \mathrm{NaOH}$ and centrifuging, the remaining liquid was measured in a colourimeter to determine the relative amount of dissolved humic acids. After the $\mathrm{NaOH}$ treatment a careful decanting of the sample was done to separate the coarse minerogenic matter. The amount of this was measured and 
used to calculate the content of sand and coarse silt in the sediment. After acetolysis the clayey samples were sieved over a $7 \mu \mathrm{m}$ net to get rid of finer material. The method is slightly modified after CWYNAR et al. (1979).

The pollen diagrams were computer drawn ('polldata' BIRKS 1979). Pollen sum and the composite diagram is based on all terrestrial pollen.

\section{Indicators of isolation and inundation during early Holocene time}

Loss on ignition is a good indicator and it always seems to rise during and after the isolation. The amount of humic acids shown by colour of $\mathrm{NaOH}$ extract reacts as 'loss on ignition' on isolation, but seems to be more sensitive.

BJÖRCK (1979) and BJÖRCK et al. (1982) shows that susceptibility reaches higher values just before the isolation, and decreases thereafter. The amount of sand and coarse silt seems to be directly related to susceptibility.

Pediastrum is often a good indicator, increasing close to and after isolation because of a more favourable environment (BERGLUND 1966).

Pollen concentration does also seem too be a good indicator, probably because of the regression bringing the vegetation closer to the coring point, and that the sedimentation rate is normally higher during the Baltic stages thus diluting the pollen.

\section{Djupeträskesjön}

(UTM coord. zone $33 \mathrm{x}=634340 \mathrm{y}=57950$.)

The lake is situated in a small valley with a narrow outlet, $5 \mathrm{~km}$ north of Oskarshamn. The lake area is $110000 \mathrm{~m}^{2}$. Maximum depth in the eastern part is $15 \mathrm{~m}$ and in the western bay where the corings were carried out the depth is around $6 \mathrm{~m}$.

The altitude noted on the map 'flygfotokartan' is $16 \mathrm{~m}$ a.s. 1 . and the threshold has not yet been investigated.

Description of the local pollen assemblage zones

Zone D 1 (Fig. 2) named Betula-Pinus. Relatively high Betula, dominated by Pinus, Empetrum reaches its highest value in this zone. Poaceae and Cyperaceae are the dominating herbs.

Zone D 2 named Betula-Pinus-Hippophaë-Juniperus-Polypodiaceae. Betula is relatively high. The Hippophaë maximum and the high Juniperus values are characteristic. Spores of Polypodiaceae expands here.

Zone D 3 named Betula-Juniperus. Characterized by a marked Betula peak and high Juniperus values. At the end of the zone Betula and Juniperus decrease markedly and the Pinus values increase. Artemisia almost disappears at the end of the zone and Ulmus attains low values. 


\section{DJUPETRÄSKESJÖN}

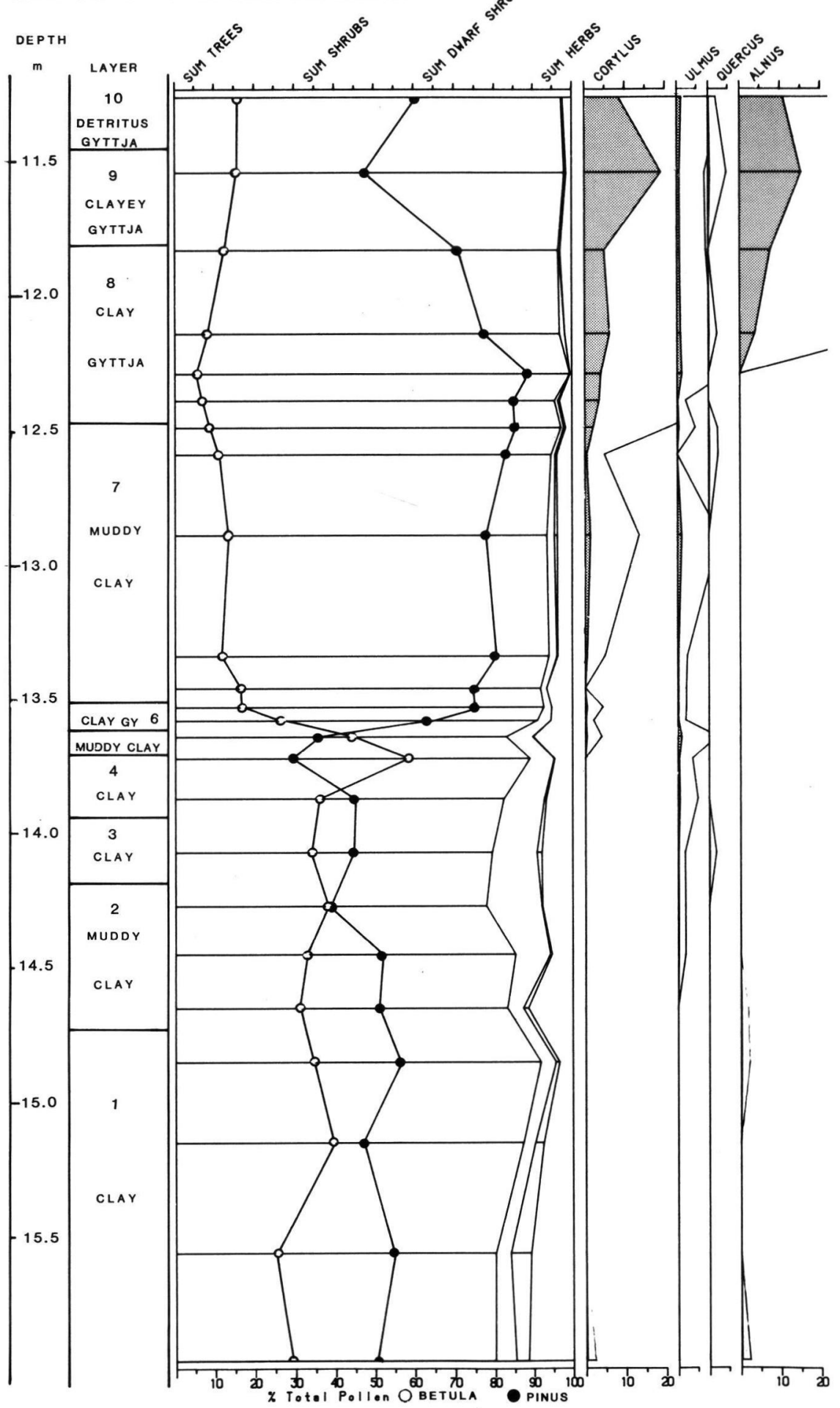

Fig. 2: Pollen diagram from Djupeträskesjön 


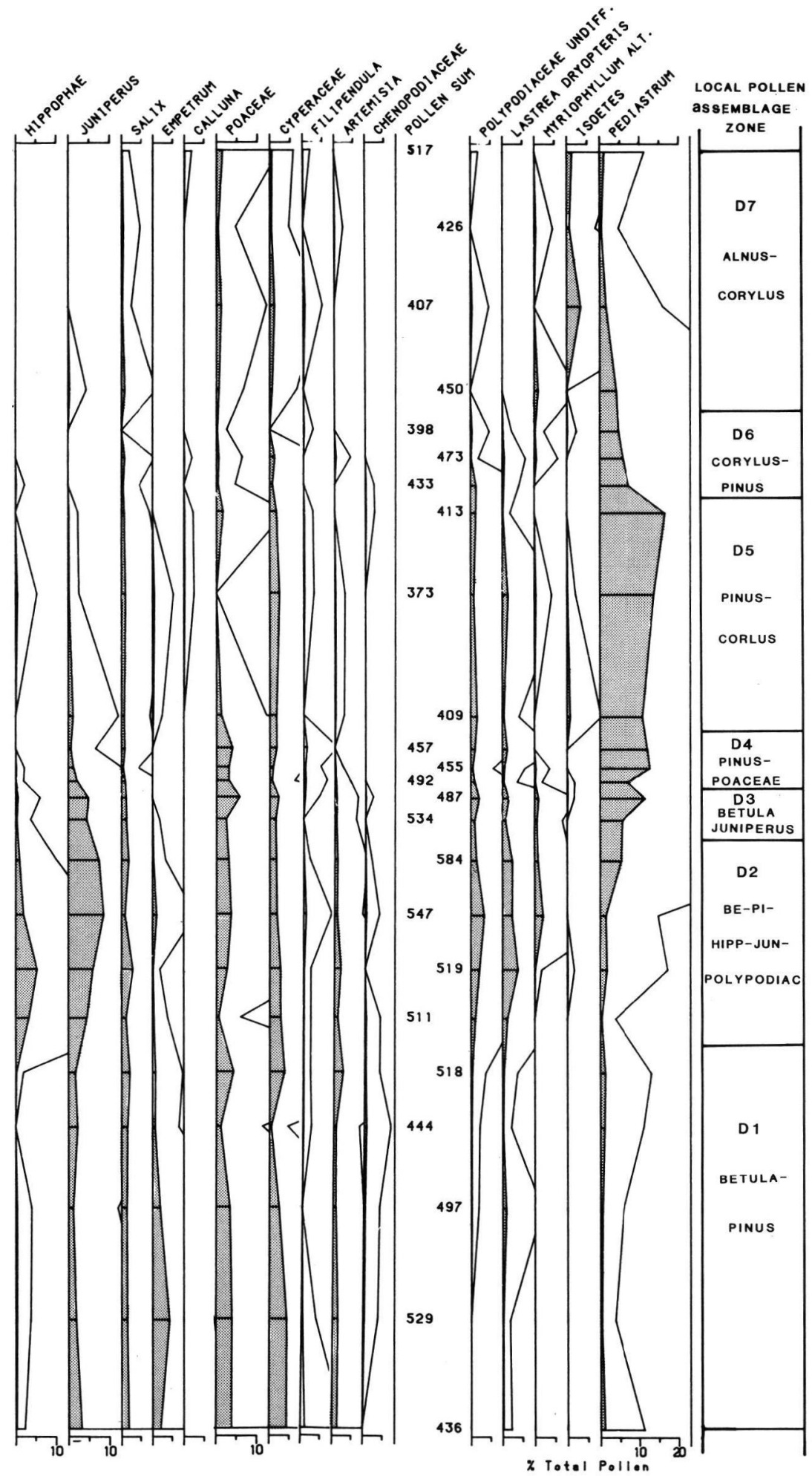


Tab. 1: Stratigraphy of the Djupeträskesjön cores

\begin{tabular}{|c|c|c|}
\hline $\begin{array}{l}\text { Depth below } \\
\text { surface }(\mathrm{m})\end{array}$ & $\begin{array}{l}\text { layer } \\
\text { no. }\end{array}$ & Description \\
\hline
\end{tabular}

\begin{tabular}{|c|c|c|}
\hline $0-6.73$ & & Water \\
\hline $6.73-10.00$ & & Not investigated \\
\hline $10.00-11.45$ & 10 & $\begin{array}{l}\text { Fine detritus gyttja, brown } \\
\text { Composition: Ld } 4 \text {, elas } 2\end{array}$ \\
\hline $11.45-11.81$ & 9 & $\begin{array}{l}\text { Clayey gyttja, brown } \\
\text { Composition: } \operatorname{Ld} 3, \mathrm{As} 1, \mathrm{Ag}+\text {, elas } 2 \text {, limes sup. } 2\end{array}$ \\
\hline $11.81-12.45$ & 8 & $\begin{array}{l}\text { Clay gyttja, FeS laminated, dark grey } \\
\text { Composition: As } 3, \mathrm{Ld} 1, \mathrm{Ag}+\text {, elas } 2 \text {, limes sup. } 0\end{array}$ \\
\hline $12.45-13.52$ & 7 & $\begin{array}{l}\text { Muddy clay, slight FeS laminated, grey } \\
\text { Composition: As } 4, \mathrm{Ld}+\text {, elas } 1 \text {, limes sup. } 0\end{array}$ \\
\hline $13.52-13.63$ & 6 & $\begin{array}{l}\text { Clay gyttja, finely laminated, partly indistinct } \\
\text { mean thickness of } 24 \text { lamina } 0.65 \mathrm{~mm} \text {, dark brownish grey } \\
\text { Composition: As } 3, \mathrm{Ld} 1, \mathrm{Ag}+\text {, elas } 2.5 \text {, limes sup. } 0\end{array}$ \\
\hline $13.63-13.71$ & 5 & $\begin{array}{l}\text { Muddy clay, slight FeS laminated, light brownish grey } \\
\text { Composition: } \mathrm{As} 4, \mathrm{Ld}+, \mathrm{Ag}+, \text { elas } 1 \text {, limes sup. } 3\end{array}$ \\
\hline $13.71-13.92$ & 4 & $\begin{array}{l}\text { Silty clay, grey } \\
\text { Composition: } \mathrm{As} 4, \mathrm{Ag}+, \mathrm{Ga}+, \mathrm{Ld}(+) \text {, elas } 0 \text {, limes sup. } 0\end{array}$ \\
\hline $13.92-14.19$ & 3 & $\begin{array}{l}\text { Clay, slight FeS laminated, grey } \\
\text { Composition: } \operatorname{As} 4, \mathrm{Ag}+, \operatorname{Ld}(+) \text {, elas } 0 \text {, limes sup. } 0\end{array}$ \\
\hline $14.19-14.73$ & 2 & $\begin{array}{l}\text { Muddy clay, Heavy FeS coloured, dark grey } \\
\text { Composition: } \mathrm{As} 4, \mathrm{Ag}+, \mathrm{Ld}+\text {, elas } 1 \text {, limes sup. } 0\end{array}$ \\
\hline $14.73-16.25$ & 1 & $\begin{array}{l}\text { Clay, with sparse thin diatom layers, grey } \\
\text { Composition: } \mathrm{As} 4, \mathrm{Ag}+\text {, elas } 0 \text {, limes supp. } 0\end{array}$ \\
\hline $16.25-19.39$ & & Not yet investigated \\
\hline
\end{tabular}

Zone D 4 named Pinus-Poaceae. Dominated by rising Pinus values and relatively high Poaceae and Filipendula frequencies which both decrease at the end of the zone.

Zone D 5 named Pinus-Corylus. Dominated by Pinus and characterized by low but continuous Corylus values.

Zone D 6 named Corylus-Pinus. Corylus values are rising. Polypodiaceae is decreasing. 
Zone D 7 named Alnus-Corylus. Characterized by rapidly rising Alnus values and a further increase of Corylus frequencies.

\section{Interpretation}

The clay in layer 1 (Tab. 1 ) indicates sedimentation in deep water. Layer 2 , muddy clay with a slightly rising organic content (not discernible in the loss on ignition curve) and slightly higher pollen concentration (Fig. 3) together with high values of humic acids and susceptibility, seems to indicate a lower water level in first part of pollenzone D 2. The clay in layer 3 and 4 with low pollen concentration and low susceptibility indicates sedimentation in deeper water thus probably showing a minor transgression.

Tab. 2: Stratigraphy of the Bastgölen cores

$\begin{array}{lll}\text { Depth below } & \text { layer } & \text { Description } \\ \text { surface }(\mathrm{m}) & \text { no. } & \end{array}$

\begin{tabular}{|c|c|c|}
\hline $0.00-1.20$ & & Water \\
\hline $1.20-3.00$ & & Not investigated \\
\hline $3.00-3.28$ & & Coarse detritus gyttja \\
\hline $3.28-4.74$ & 8 & $\begin{array}{l}\text { Fine detritus gyttja, brown } \\
\text { Composition: } \mathrm{Ld} 4, \mathrm{Ag}+\text {, elas } 3\end{array}$ \\
\hline $4.74-4.82$ & 7 & $\begin{array}{l}\text { Clayey silty gyttja, brown } \\
\text { Composition: } \operatorname{Ld} 2, \operatorname{As} 1, \operatorname{Ag} 1, \mathrm{Ga}+\text {, elas 2, limes sup. } 1\end{array}$ \\
\hline $4.82-4.99$ & 6 & $\begin{array}{l}\text { Clayey gyttja, brown } \\
\text { Composition: } \operatorname{Ld} 3, \mathrm{As} 1, \mathrm{Ag}+\text {, elas 3, limes sup. } 0\end{array}$ \\
\hline $4.99-5.11$ & 5 & $\begin{array}{l}\text { Fine detritus gyttja, darkbrown } \\
\text { Composition: } \mathrm{Ld} 4, \mathrm{As}+, \mathrm{Ag}+\text {, elas } 4 \text {, limes sup. } 1\end{array}$ \\
\hline $5.11-5.15$ & 4 & $\begin{array}{l}\text { Clay-gyttja, brown } \\
\text { As } 2, \mathrm{Ld} 2, \mathrm{Ag}+, \text { elas } 1 \text {, limes sup. } 0\end{array}$ \\
\hline $5.15-5.21$ & 3 & $\begin{array}{l}\text { Muddy clay, light brown } \\
\text { Composition: As } 4, \mathrm{Ld}+, \mathrm{Ag}+\text {, elas } 1 \text {, limes sup. } 0\end{array}$ \\
\hline $5.21-5.49$ & 2 & $\begin{array}{l}\text { Clay, grey } \\
\text { Composition: } \mathrm{As} 4, \mathrm{Ag}+, \text { elas } 0 \text {, limes sup. } 1\end{array}$ \\
\hline $5.49-6.05$ & 1 & $\begin{array}{l}\text { Clay, silt and sand in layers, grey } \\
\text { Composition: } \operatorname{As} 2, \operatorname{Ag~} 1, \mathrm{Ga} 1 \text {, elas } 0 \text {, limes sup. } 3 \\
\text { Cored to stop }\end{array}$ \\
\hline
\end{tabular}




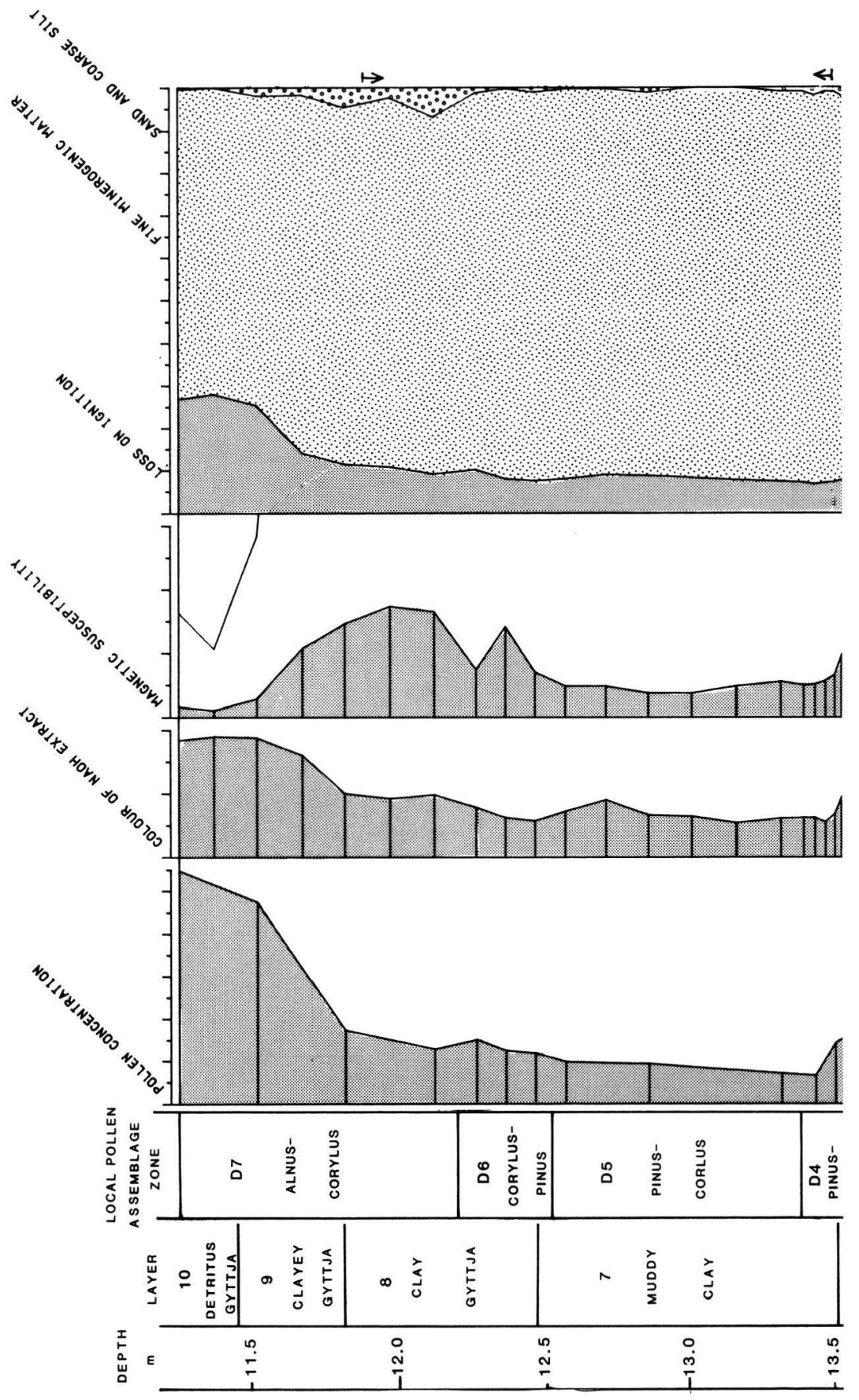




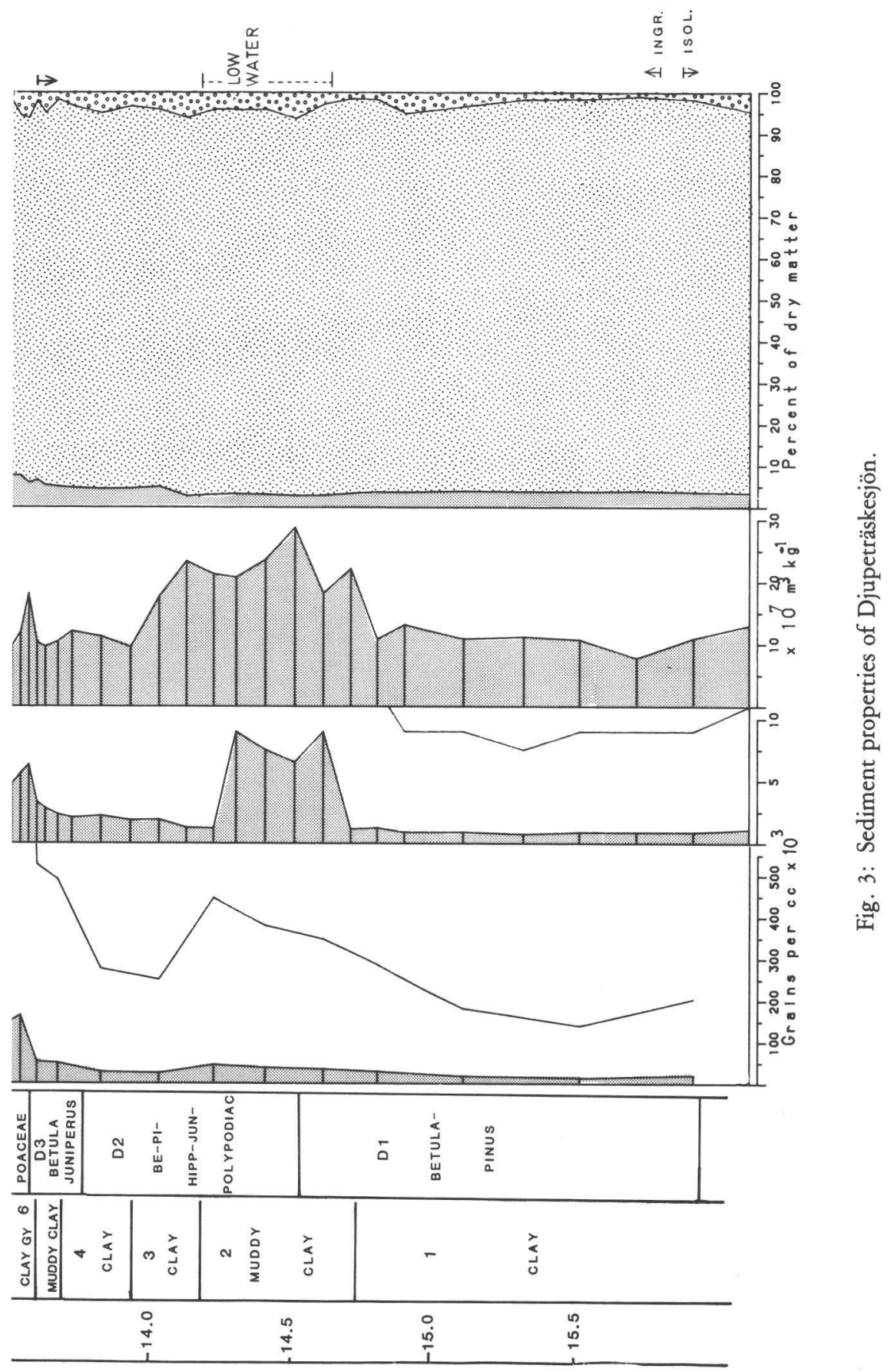




\section{BASTGÖLEN}

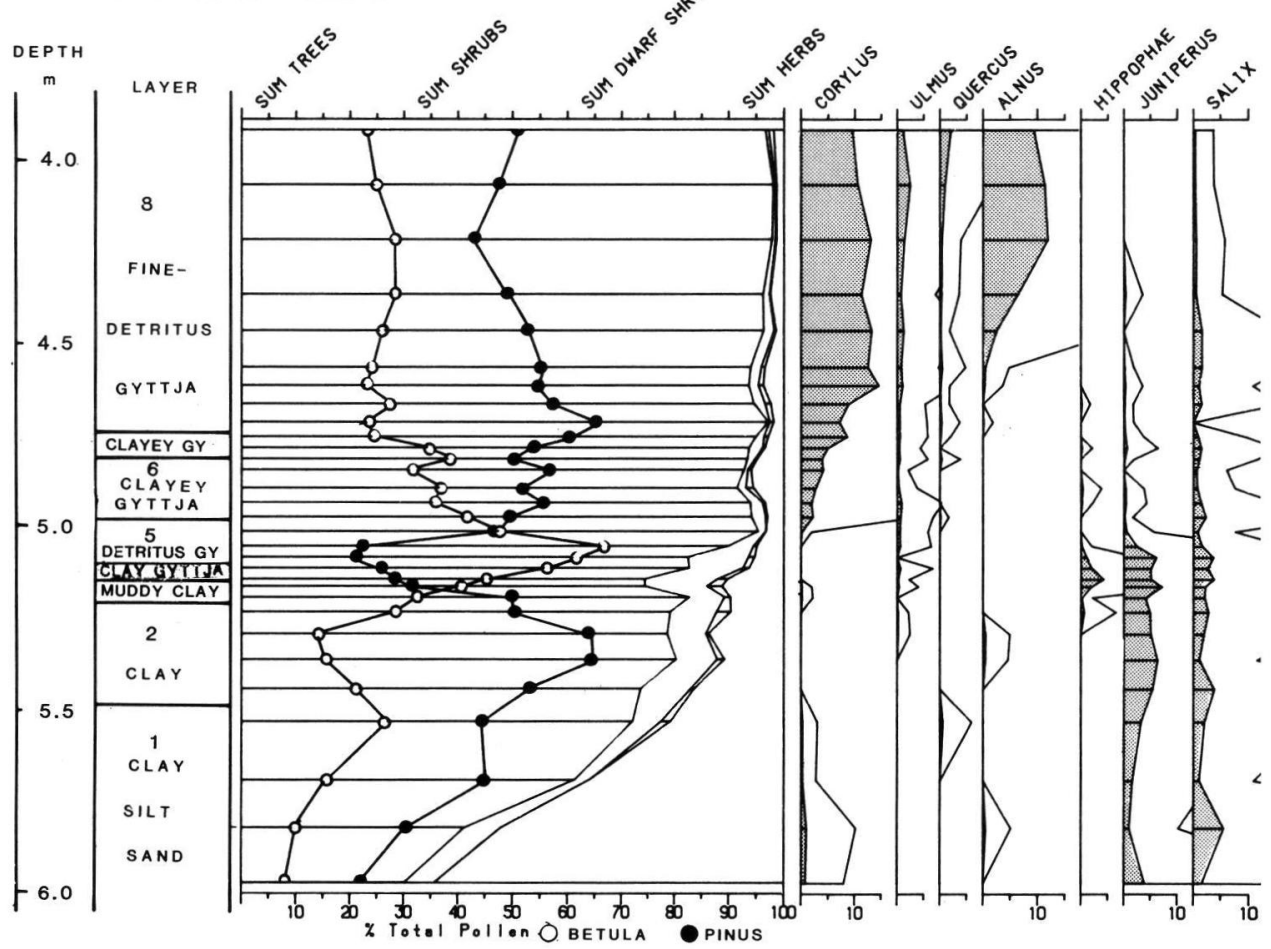

Fig. 4: Pollen diagram from Bastgölen.

In layer 5, muddy clay, the loss on ignition is slightly rising and magnetic susceptibility reaches a peak. It is possible that the basin is isolated from the Baltic in the upper part of this layer, that is in the upper part of pollen zone D 3. The low loss on ignition together with a relatively high amount of coarse minerogenic matter in layer 6 could indicate that the basin was a sheltered lagoon, never completely isolated. The high minerogenic content could else perhaps be explained by erosion of clayey sediments in the surroundings of the isolated lake.

The lamina in layer 6 is interpreted as annual varves, their mean thickness is $0.65 \mathrm{~mm}$ indicating that the layer is deposited in $150-200$ years.

A transgression of the Baltic into the basin is indicated by layer 7 and layer 8 shows on a more shallow water with an isolation in the upper part, indicated mainly by the rising loss on ignition and the preceding high values of susceptibility. The isolation takes place in pollen zone D 7 .

\section{Bastgölen}

(UTM coordinates zone $33 \mathrm{x}=634340 \mathrm{y}=57950$ )

The lake is situated $10 \mathrm{~km}$ west of Oskarshamn. The area of the lake is $60000 \mathrm{~m}^{2}$ and the water depth at the coring point in the eastern bay is $1.2 \mathrm{~m}$. The altitude of 


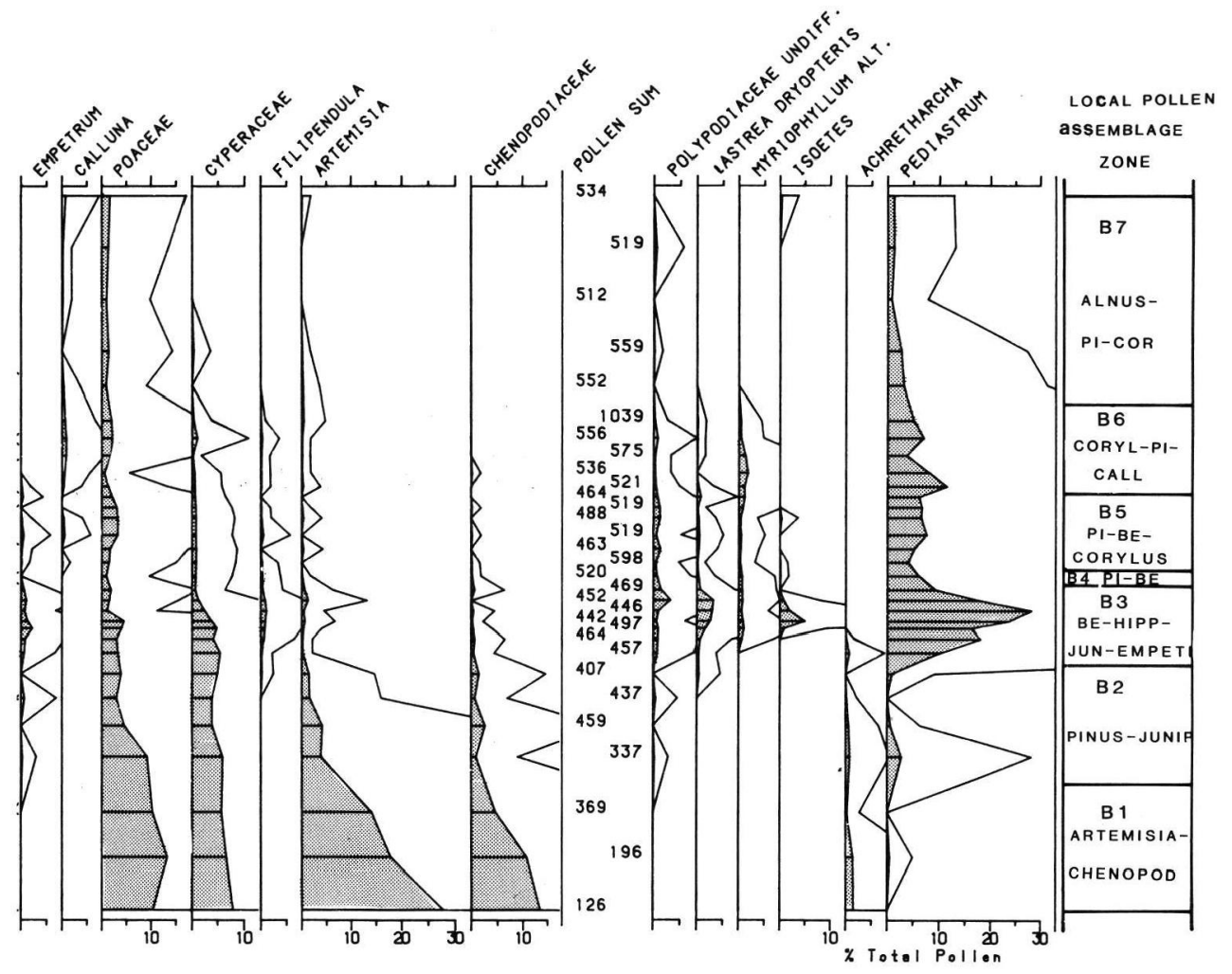

the lake is $24 \mathrm{~m}$ a.s.l. on the topographic map and the threshold seems to have been deepened with ca. $1.5 \mathrm{~m}$.

Two radiocarbon datings have been done, one in the uppermost part of layer 4 , $5.10-5.145 \mathrm{~m}$ below surface $(9840+90 \mathrm{yr}$ B.P. $)$, the second in the upper part of layer 6, 4.81-4.84 $\mathrm{m}$ below surface $(9610+90 \mathrm{yr}$ B.P. $)$.

\section{Description of the local pollen assemblage zones}

Zone B 1 (Fig. 4) named Artemisia-Chenopodiaceae-Pinus. High values of Artemisia Chenopodiaceae, Poaceae and low tree pollen values.

Zone B2 named Pinus-Juniperus. Rising and high values of Pinus, high Juniperus and decreasing Artemisia values.

Zone B3 named Betula-Hippophaë-Juniperus-Empetrum. Betula is abundant ( $70 \%)$. In this zone Hippophaë has a marked maximum as well as other shrubs (Juniperus, Salix and Empetrum) and Filipendula. All these are decreasing markedly towards the upper part of the zone. Spores of Polypodiaceae begin to occur frequently at the beginning of the zone. Ulmus is found regularly in the upper part. Worth to notify is the occurrence of pollen and spores of waterplants as Isoëtes and Myriopbyllum alterniflorum together with high Pediastrum values. 
Zone B 4 named Pinus-Betula. Betula is decreasing and Pinus increasing markedly.

Zone B5 named Pinus-Betula-Corylus. Pinus reaches high values and Betula is still decreasing. Corylus has relatively low values until the end of the zone where it increases. Polypodiaceae almost disappears at the end of the zone.

Zone B6 named Corylus-Pinus-Calluna. Increasing values of Corylus and decreasing values of Pinus. Scattered pollen of Alnus occurs and Calluna reaches a maximum.

Zone B 7 named Alnus-Pinus-Corylus. Alnus occurs frequently and increases in the upper part of the diagram where some finds of Tilia and Fraxinus occur together with increasing but low Quercus values.

\section{Interpretation}

The rising loss on ignition values and the maximum in susceptibility (Fig. 5) together with the Pediastrum rise show that the isolation takes place in layer 4 of pollen zone B 3 .

The sediment change between layers 5 and 6 (Tab. 2) with decreasing loss on ignition shows a transgression of the Baltic during the first part of pollen zone B 4 .

The second isolation takes place between layers 7 and 8 indicated by high values of susceptibility and coarse minerogenic matter.

\section{Correlation and dating of the local pollen zones}

Datings of the rational limit of Corylus and Alnus in south Sweden is shown in DigerfeldT (1982). Ten datings of Corylus rational limit between 9720 and $9360 \mathrm{yr}$ B.P. gives a mean of $9500 \mathrm{yr}$ B.P. Alnus rational limit is dated by $16 \mathrm{C}-14$ datings between 9320 and $8420 \mathrm{yr}$ B.P., with a mean of $8700 \mathrm{yr}$ B.P. Ten of those are within the $8500-8900$ yr B.P. interval. These mean values of the rational limits of Alnus and Corylus are used in Fig. 6.

The C-14 date in layer 4 in Bastgölen (9840 \pm 90 yr B.P.) dates the upper part of the Hippophaë maximum. Hippophaë seems to appear approximately at the same time in the whole of S Sweden (cf BJÖRCK 1979, 1981; BJÖRCK \& DigerfeldT 1982).

The dating of the uppermost part of layer 6 in Bastgölen $(9610 \pm 90 \mathrm{yr} \mathrm{B.P.)} \mathrm{seems}$ to be too old or indicate that layer 7 is deposited during a long time or partly eroded. A reason for the dating to be too old is that the sediment is deposited in the Ancylus Lake during or immediately after the transgression maximum. This transgression inundates areas with vegetation, mostly Pinus and Betula forest, and great amounts of older organic material must have been eroded and partly incorporated in the sediment.

Zone B 1, Artemisia-Chenopodiaceae, is correlated with zone 5 in Blekinge (BJöRCK 1979), and its upper part is assumed to be ca. $10400-10500 \mathrm{yr}$ B.P. In fig. 6 the local pollen zones are correlated and dated by comparisons and correlations with nearby investigations. 


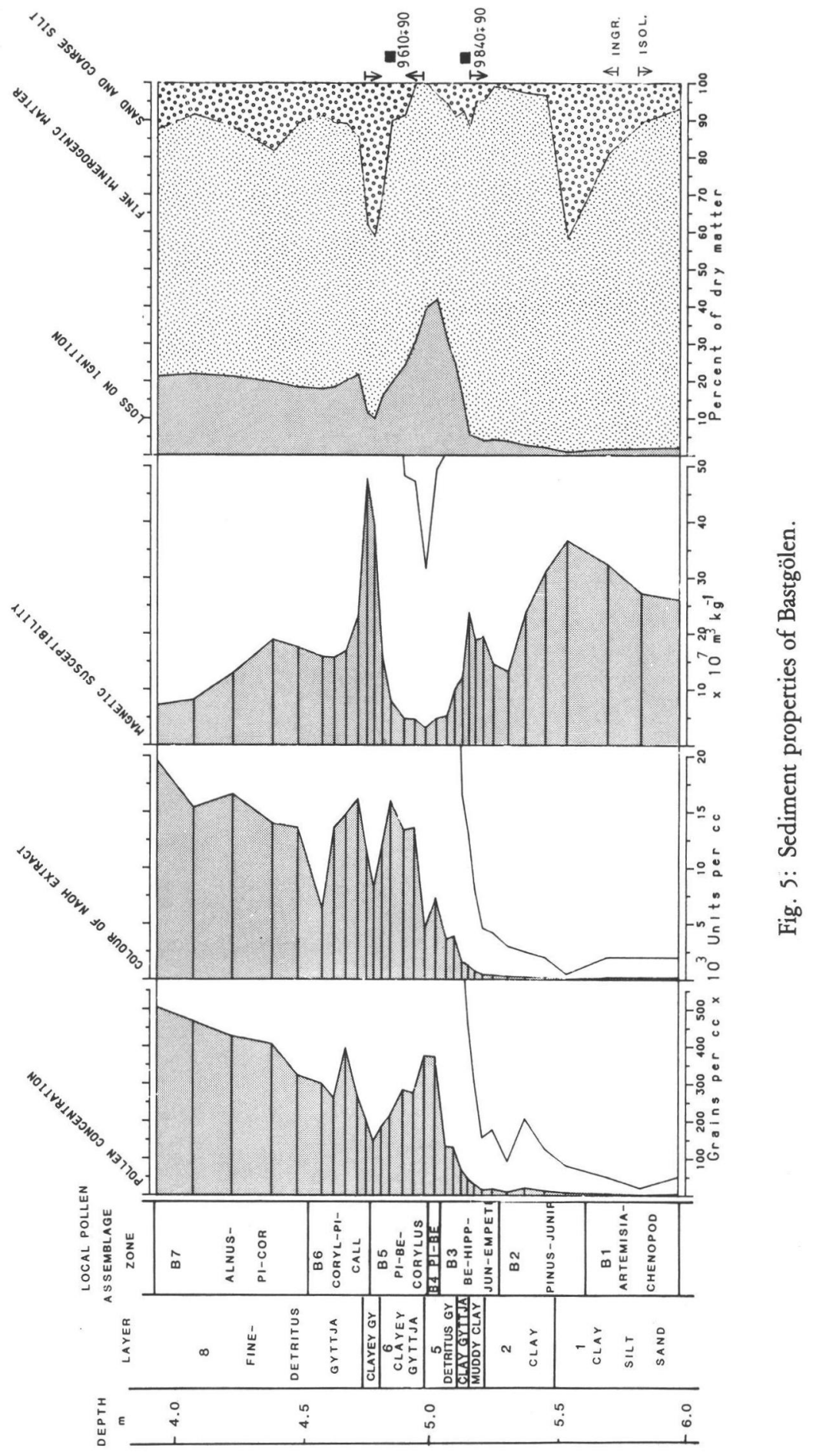




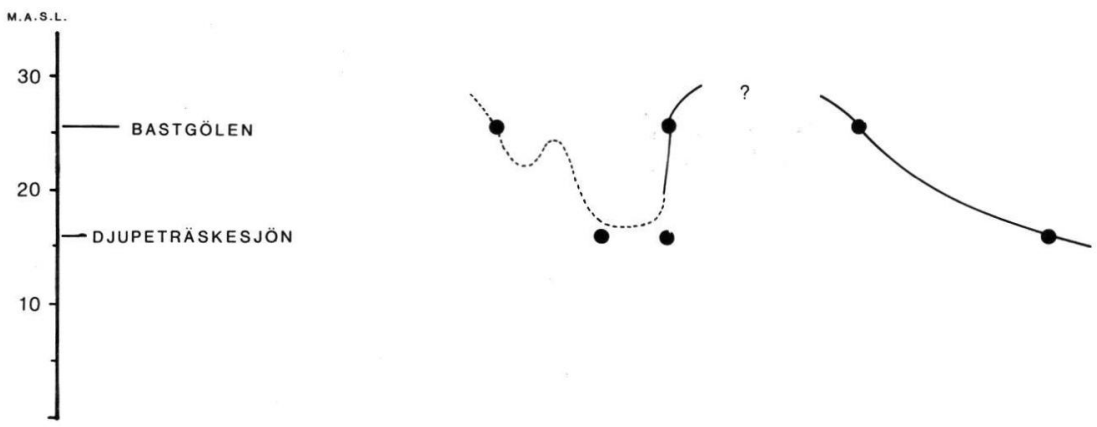

\begin{tabular}{|c|c|c|c|c|c|c|c|}
\hline $\begin{array}{c}\text { BASTGÖLEN } \\
\text { LOCAL } \\
\text { POLLEN } \\
\text { ZONES }\end{array}$ & $\begin{array}{c}\text { B1 } \\
\text { ARTEMISIA } \\
\text { CHENOPOO }\end{array}$ & $\begin{array}{c}\text { B2 } \\
\text { PI- } \\
\text { JUNIP }\end{array}$ & $\begin{array}{c}\text { BE-HIPP- } \\
\text { JUN-EMPET }\end{array}$ & P1-BE & $\begin{array}{c}\text { B5 } \\
\text { PI-BE- } \\
\text { CORYLUS }\end{array}$ & $\begin{array}{c}\text { B } \\
\text { COAYL-PI- } \\
\text { CALL }\end{array}$ & $\begin{array}{c}\text { ALNUS- } \\
\text { PI-COR }\end{array}$ \\
\hline
\end{tabular}

\begin{tabular}{|c|c|c|c|c|c|c|}
\hline $\begin{array}{l}\text { DJUPETRÄSKESJÖN } \\
\text { LOCAL } \\
\text { POLLEN } \\
\text { ZONES }\end{array}$ & $\begin{array}{c}\text { D1 } \\
\text { BETULA } \\
\text { PINUS }\end{array}$ & $\begin{array}{l}\text { D2 } \\
\text { BE-PI- } \\
\text { HIPP-JUN- } \\
\text { POLYP }\end{array}$ & \begin{tabular}{|l|c|} 
D3 & D4 \\
BE- & PI- \\
JUN & POAC \\
\end{tabular} & $\begin{array}{l}\text { D5 } \\
\text { PINUS- } \\
\text { CORLUS }\end{array}$ & $\begin{array}{c}\text { D6 } \\
\text { CORYLUS- } \\
\text { PINus }\end{array}$ & $\begin{array}{c}\text { D7 } \\
\text { ALNUS- } \\
\text { CORYLUS }\end{array}$ \\
\hline
\end{tabular}

Fig. 6: Correlation and dating of pollen zones and a preliminary shore displacement curve $10,000-8500$ yr B.P.

\section{Shore displacement}

The resulting shoreline displacement curve is shown in Fig. 6. The oldest part of the curve shows a regression from Bastgölen. This regression seems to be interrupted by a transgression indicated by the stratigraphy in Djupeträskesjön. This transgression could probably be correlated with the transgressive 'Gyrosigmasjön'. THOMASSON (1927), as well as with the Yoldia transgression in Estonia (Kessel \& RaUKAS 1979).

It seems probable that Djupeträskesjön $16 \mathrm{~m}$ a. s. 1., was never isolated during the following regression. Instead it formed a lagoon during 150-200 years. During this time a varved clay gyttja was deposited.

After this low water period a rapid transgression, correlated with the Ancylus transgression reached both Djupeträskesjön and Bastgölen without any discernible difference in time. The transgression took place at the same time as Corylus appears. Thus the transgression is dated to ca. $9500 \mathrm{yr}$ B.P. This age corresponds well with Finnish investigations (GlÜCKeRT \& Ristaniemi 1982; ERONEN \& Haila 1982) on the Ancylus transgression in South Finland. The altitude of the transgression maximum is not known in detail but according to a isobase map in MUNTHE (1904) it should reach ca. $35 \mathrm{~m}$ a.s. 1 .

The Ancylus regression seems to begin early, probably around $9000 \mathrm{yr}$ B.P. Djupeträskejön is isolated around 8500 and the regression seems to have been slow at this altitude. 


\section{Acknowledgements}

I wish to thank my supervisor Dr. SvANTE BJöRCK for criticaly reading and discussing the manuscript and for his help during field work, Dr. PER SANDGREN for field assistance and GuNNEL ARNESSON for improving the illustrations. This work is financially supported by the Swedish Natural Science Recearch council (NFR).

\section{References}

BERGLUND, B. E. (1966): Late-Quaternary vegetation in eastern Blekinge, southeastern Sweden. I. Late-Glacial time. - Opera Botanica 12 (2): 180 pp; Lund.

BIRKs, H. J. (1979): Numerical methods for zonation and correlation of biostratigraphical data. — In: Project guide I Dept. of Quat. Geol. Lund, I: 99-123; Lund.

BJöRCK, S. (1979): Late Weichselian stratigraphy of Blekinge, SE Sweden and waterlevel changes in the Baltic Ice Lake. - Univ. of Lund, Dept. of Quat. Geol. Thesis 7: 245 pp; Lund.

- (1981): A stratigraphic study of Late Weichselian deglaciation, shore displacement and vegetation history in south-eastern Sweden. - Fossils and Strata, 14: 93 pp; Oslo.

-, Dearing, J. A. \& Jonsson, A. (1982): Magnetic susceptibility of Late Weichselian deposits in southeastern Sweden. - Boreas, 11: 99-111; Oslo.

- \& Digerfeldt, G. (1982): Late Weichselian shore displacement at Hunneberg, southern Sweden, indicating complex uplift. - Geol. fören. Stockh. förh., 104: 132-155; Stockholm.

Cwynar, L. C., Burden, E. \& Andrews, J. H. (1979): An inexpensive sieving method for concentrating pollen and spores from fine-grained sediments. - Can. J. Earth Sci., 16: 1115-1120; Calgary.

Digerfeldt, G. (1982): The Holocene development of Lake Sämbosjön. 1. the regional vegetation history. - Univ. of Lund, Dept. of Quat. Geol. Report 23: 24 pp; Lund.

Eronen, M. \& Haila, H. (1982): Shoreline displacement near Helsinki, southern Finland during the Ancylus Lake stage. - Ann. Acad. Sci. Fenn., ser. A III, 134: 111-140; Helsinki.

Glưckert, G. \& Ristaniemi, O. (1982): The Ancylus transgression west of Helsinki South Finland-A preliminary report. - Ann. Sci. Fenn. ser. A III, 134: 99-110; Helsinki.

Kessel, H. \& Raukas, A. (1979): The Quaternary history of the Baltic. Estonia. - In V. Gudelis and L. K. Königsson (editors), The Quaternary history of the Baltic. - Acta Univ. Ups. Symp. Univ. Ups. Ann. Quing. Cel. 1: 127-146; Uppsala.

Königsson, L.-K. (1968): The Ancylus transgression in the Skede mose area, Öland. - Geol. Fören. Stockh. Förh., 90: 5-36; Stockholm.

LundQvist, G. (1928): Studier i Ölands myrmarker. - Sver. Geol. Unders., C 353: 177 pp; Stockholm.

Munthe, H. (1902): Beskrivning till kartbladet Kalmar. - Sver. Geol. unders., Ac 6: 119 pp; Stockholm.

- (1904): Beskrivning till kartbladet Mönsterås med Högsby. - Sver. Geol. unders., Ac 8: $132 \mathrm{pp}$; Stockholm. 
Stockmarr, J. (1971): Tablets with spores used in absolute pollen analysis. - Pollen et Spores, 13: 615-621; Paris.

Thomasson, H. (1927): Baltiska tidsbestämningar och baltisk tidsindelning vid Kalmarsund. — Geol. Fören. Stockh. Förh., 49: 21-76; Stockholm.

- (1935): Äldre baltiska skeden. - Geol. Fören. Stockh. Förh., 57: 599-625; Stockholm.

Troels-Smith, J. (1955): Karakterisering af lфse jordarter. - Danm. Geol. Unders. IV. series Vol 3 no 10: 38-73; Kфbenhavn.

Manuscript accepted October 1984 